\title{
HUSBAND AND WIFE RELATIONSHIP OF EARLY MARRIAGE \\ IN TANGGA ULIN VILLAGE \\ (According to the Review of the Book of \\ Uqud Al-Lujain Fi Bayan Huquq al-Zaujain)
}

\author{
Risma Monirah \\ Faculty of Sharia IAIN Samarinda \\ rismamonirah14@gmail.com \\ Akhmad Sofyan \\ Faculty of Sharia IAIN Samarinda \\ zainurrahim1192@gmail.com
}

\begin{abstract}
Early marriage is a marriage that is carried out under the age specified by law. Usually, couples who do early marriages are very susceptible to disputes that result in divorce. The researcher wants to reveal, about the relationship pattern of married couples who carry out early marriages in Tangga Ulin Village, Hulu Sungai Utara Regency, where in that village there are many scholars and religious leaders who of course teach the book 'Uqūd al-Lujain fi Bayān Huqūq al-Zaujain. In addition, the researcher wants to know the review of the book 'Uqūd al-Lujain fi Bayān Huqūq al-Zaujain on the relationship patterns of husband and wife who carry out these early marriages. This research uses qualitative research with a normative empirical approach. The result of this research is The husband and wife relationship of the perpetrators of early marriage in Tangga Ulin Village applies a husband and wife relationship pattern that is not bound (flexible), in carrying out their respective rights and obligations to help and understand each other between partners, so that they can ease the work and responsibilities that exist in their household. Then, according to the book 'Uqūd alLujain fi Bayān Huqūq al-Zaujain especially the section "wives are encouraged to realize that they are like slaves to their husbands." However, in its application, it applies a pattern of mutual help and understanding (flexible) relationships. Thus, it is hoped that divorce will not occur again due to early marriage.
\end{abstract}

\section{Keywords: Early marriage, husband and wife relations, the book 'Uqūd al-Lujain fi Bayān Huqūq al-Zaujain}

\section{A. Preliminary}

In the book 'Uqūd al-Lujain fi Bayān Huqūq al-Zaujain, it is explained that the Prophet Muhammad said: "The rights of a wife which must be fulfilled by a husband: 1) Give food to his wife when her husband eats, 2) Give clothes to the wife when her husband is dressed, 3) Not hitting his wife in the face, 4) Not scolding his wife, and 5) Not being indifferent to his wife except in bed "(HR at-Thabrani). ${ }^{1}$

Meanwhile, it is advisable for a wife to realize that she is like her husband's slave, so that she is not allowed to use her husband's property except with his

\footnotetext{
${ }^{1}$ Imam Nawawi al-Bantani, 'Uqūd al-Lujain fi Bayān Huqūq al-Zaujain, Terj. M. Nasif,
} Keluarga Berkah: Meraih Kebahagiaan Dunia Akhirat, Cet. I, (Kediri: Turast 2011 \& Lirboyo Press, 2014), h. 26-27. 
permission. Some scholars argue that a wife should not use her assets except with the husband's permission, because she is like a woman who is limited to using assets. ${ }^{2}$

The relationship husband and wife in early marriage partners is a pattern of relationships husband and wife who are married at a minor age determined by law, where in living their household life they are able to build a harmonious family. The application of the husband and wife relationship of an early marriage partner is influenced by several things, including the educational background and age of the couple. For couples with low education, of course, there is a difference in the application of the relationship husband and wife compared to couples with high education. This is because couples who have a high level of education will understand good relationships in fostering a household. Likewise from the age background, if the young couple is married under age (the age of marriage is under the age stipulated in Law No. 16 of 2019) then in establishing a husband and wife relationship will experience obstacles in the form of not understanding the rights and obligations of the partner. This is because the way people think at each age has a difference, especially in the level of maturity. However, the researchers will examine early marriage couples who are able to live permanently (the age of marriage reaches 5 years or more) while they are married under the age specified in the law.

In this study, the authors conducted a legal review of the application of the book 'Uqūd al-Lujain fi Bayān Huqūq al-Zaujain by a young married couple. In fact, what happens in the field is very different from what is contained in the book 'Uqūd al-Lujain fi Bayān Huqūq al-Zaujain. In the book, it explains that a wife is like a husband's slave, but not the real meaning of slave, but aims to show the similarity between a wife and a slave who must obey her husband to build a harmonious household, because the husband is a leader who has responsibility to a wife. Whereas in modern times, between husbands and wives who practice early marriage, most wives are not described as having obedience to their husbands as described in the book 'Uqūd al-Lujain fi Bayān Huqūq al-Zaujain.

In Hulu Sungai Utara District, there are 10 Districts, one of which is Central Amuntai District. Amuntai Tengah District is a district that has the highest number of ulama among other districts in Hulu Sungai Utara Regency. In Amuntai Tengah Subdistrict, there are 74 ulama, 3 religious counselors, and 57 majelis ta'lim. In Amuntai Tengah Subdistrict, there are 29 villages, one of which is Tangga Ulin Village where there are 7 prayer rooms and each prayer room is held on certain days of each

22 Imam Nawawi al-Bantani, 'Uqūd..., h. 53-54. 
week, and there are 4 recitation places which are held regularly once a week. Across the village of Tangga Ulin there is also an Al-Ma'arif recitation place which is held every morning, and most of the congregation are residents of Tangga Ulin Village. ${ }^{3}$

In Tangga Ulin Village, many people live in harmony with the background of early marriage. Although they do early marriages due to factors from parents who encourage their children to marry early or to avoid promiscuity. With many scholars in Tangga Ulin Village and many recitations being held there, as well as many religious leaders who deliver lectures related to households in general and husband and wife relations in particular, and one of the references in the lecture is the book 'Uqūd alLujain fi Bayān Huqūq al-Zaujain, of course many also know about the book 'Uqūd alLujain fi Bayān Huqūq al-Zaujain because the book is explained in several recitations. More or less people understand the book, plus the condition of a religious community because the majority are Muslim, so that the relationship between early marriage partners can be used as the subject of research. What is the relationship pattern husband and wife who are perpetrators of early marriage in Tangga Ulin Village? And what is the perspective of the book 'Uqūd al-Lujain fi Bayān Huqūq al-Zaujain on the relationship pattern of husband and wife who do early marriage in Tangga Ulin Village?

As for the previous research in this article, namely, the Thesis written by Muhammad Daviq Fadhly entitled " Hak dan Kewajiban Istri Sebagai Wanita Karir Tinjauan Kitab Uqudullujain dan Fiqih Wanita Yusuf Qardhawi" in 2017. In this thesis raises the issue of the rights and obligations of the wife as a career woman, a review of the Uqudullujain book and the Yusuf Qardhawi Women's Jurisprudence book and the differences between the two. In this thesis finds the fact that there are differences in granting women's permission for careers. According to the book Uqudullujain must get permission from the husband, whereas according to fiqh women do not have the husband's permission, but what kind of work is allowed by the husband, and this is more suitable to be applied today. The difference between the author's research and the writing is in the main content of the discussion. In this thesis discusses the rights and obligations of a wife as a career woman in terms of the book Uqudullujain and the book of Fikih Wanita Yusuf Qardhawi, while in the writings the author discusses the relationship between husband and wife who do early marriage which is reviewed only from the book 'Uqūid al-Lujain fi Bayān Huqūq al -Zaujain.

Another previous research is the Thesis written by Nanda Himmatul Ulya

\footnotetext{
3 Badan Pusat Statistik HSU, Kabupaten Hulu Sungai Utara Dalam Angka 2016, (Hulu Sungai Utara: BPS-Hulu Sungai Utara, 2016), h. 253.
} 
entitled "Husband and Wife Relationship Patterns in Differences in Social Status" in 2015. In this thesis discusses the relationship patterns of husband and wife, where the social status of the wife is higher than that of the husband, and differences This affects the relationship between the two, as well as the views of the people of Malang City on the implementation of kafa'ah in marriage. Then obtained by the fact that the division of labor (domestic) between husband and wife shared with a pattern of cooperation, and the concept of marriage is not only a religion but also in terms of social status, moral, and economic. The difference between the research above and the researcher's writings lies in the subject matter, namely this study analyzes the pattern of husband and wife relations in differences in social status, but does not conduct a review based on the book 'Uqūid al-Lujain fi Bayān Huqūq al-Zaujain, while in this thesis the researcher discusses the relationship between husband and wife perpetrators of early marriage then conduct a review of the book 'Uqūid al-Lujain fi Bayān Huqūq al-Zaujain.

\section{B. Theoretical Review}

\section{Definition of Marriage}

Marriage in Arabic is marriage, derived from the word nakaha yankihu nikahan, which means mixed. The Indonesian dictionary means an agreement between men and women. ${ }^{4}$

Marriage is a physical-mental bond between a man and a woman as husband and wife which aims to form a happy and eternal family (household) based on the Supreme Lordship. ${ }^{5}$ Meanwhile, according to the Komplasi Islamic Law (KHI) Article 2 Marriage according to Islamic law is marriage, which is a very strong contract or mitssaqan ghalidzan to obey Allah's orders and carry out it is worship. ${ }^{6}$

The scholars of the four mazhab define marriage with various meanings, but among these differences there are similarities between one another, including: ${ }^{7}$

a. Mazhab Hanafi defines marriage as a contract which means having and having fun on purpose, meaning that with a marriage contract in the form of a marriage contract (handover between the guardian and the man who will

\footnotetext{
${ }^{4}$ Didi Jubaedi Ismail and Maman Abdul Djaliel, Membina Rumah Tangga Islam di Bawah Rida Illahi, (Bandung: Pustaka Setia, 2000), h. 63.

${ }^{5}$ Pasal 1 Bab 1 Dasar Perkawinan Undang-Undang Nomor 1 Tahun 1974.

${ }^{6}$ Pasal 2 Kompilasi Hukum Islam

${ }^{7}$ Abdurrohman Al-Jaziri, Al-Fiqh Ala Al-Madzahib Al-Arba'ah, Cet I, (Lebanon: Darul Kutub Al-Ilmiah Beirut, 2013), h. 8-9
} 
become her husband), namely with the marriage contract, it becomes because of the ownership of each husband and wife.

b. Mazhab Shafi'i defines marriage as a contract that contains the legal provisions of watha' (intercourse) with the pronunciation of nikah or tajwiz or that is the same as both.

c. Mazhab Malik, defines marriage as a contract that contains legal provisions solely to allow watha' or (intercourse), have fun and enjoy what is in a woman who is allowed to marry him.

d. Mazhab Ahmad bin Hanbal, defines marriage as a contract by using the pronunciation of nikah or tajwiz to allow benefits and have fun with women.

2. Legal Basis of Marriage

a. Al-Qur'an

1) QS. Ar-Rum (30): 21

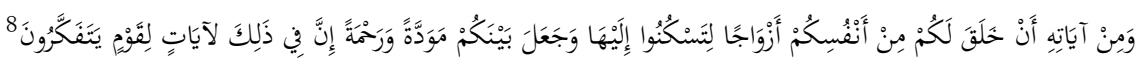

Translation: "And among the signs of His power is He created for you wives of your own kind, so that you may tend and feel at ease with them, and He made among you a sense of love and affection. Verily in this is truly there are signs for those who think". (QS. Ar-Rum (30) : 21)

Included among Allah's perfect graces to Adam's children was that He made their spouses (wives) of their own kind, and made a sense of love and affection between them. Because sometimes a man stays with a woman out of love for him or because of affection for him, because he has children from him, or vice versa because a woman needs protection from him or requires a living from him, or both like each other, and other reasons. The signs of Allah subhanahu wa ta'ala with His power and greatness that are perfect are really there for people who are always thinking and learning about it. ${ }^{9}$

2) QS. Adz-Dzariyat (51): 49

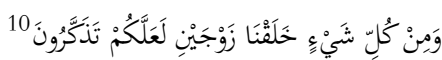

Translation: "And everything We created in pairs so that you remember the greatness of Allah". (QS. Adz-Dzhariyat (51) : 49)

\footnotetext{
${ }^{8}$ Kementerian Agama RI, Al-Qur,an Madina, (Bandung: PT Madina Raihan Makmur, 2013), h. 406

${ }^{9}$ Muhmmad Nasib Ar-Rifai, "Taisiru al-Aliyyul Qadir li Ikhtishari Tafsir Ibnu Katsir" Terj., Syihabuddin, Kemudahan dari Allah: Ringkasan Tafsr Ibnu Katsir, Cet. I (Jakarta: Gema Insani, 1999), h. 378.

10 Kementerian Agama RI, Al-Qur,an ..., h. 522.
} 
All beings are created in pairs, earth and sky, night and day, sun and moon, land and sea, light and dark, faith and disbelief, dead and alive, wretched and happy, and heaven and hell, to all living things. So that you know for sure that God Who Created all of them is One, there is no partner for Him. ${ }^{11}$

3) QS. An-Nur (24) : 32

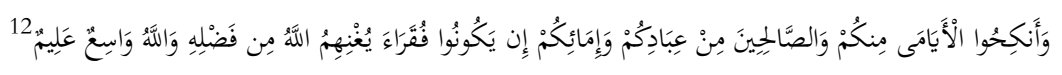

Translated: "And marry those who are alone among you, and those who are worthy (married) from your male servants and female servants. If they are poor Allah will enrich them with His grace. And Allah is vast (His gift), All-knowing ". (QS. An-Nur (24) :32)

This is a commandment to marry. Some scholars argue that everyone who is able to get married is obliged to do so. Because in fact the function of mating is to lower the eyes and maintain the genitals. And whoever is unable, let him fast, because actually fasting can be used as a damper (lust) for him. Allah commanded free people and slaves to marry, and He promised them to provide sufficient. ${ }^{13}$

b. Hadith

Commands about marriage not only in the Qur'an but many also commands about marriage contained in the hadith of the Prophet Muhammad to his community to perform marriages, including the following:

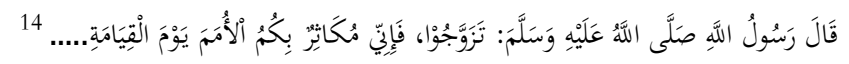

Meaning: "Get married, because really I will boast of your number to the other ummah on the Day of Resurrection". (H.R. al-Baihaqi)

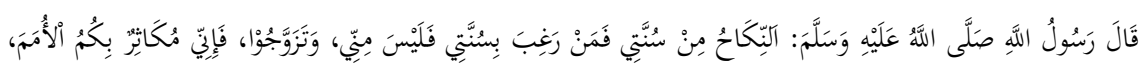

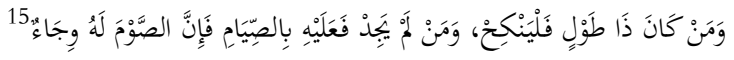

Meaning: "Getting married is my sunnah. Whoever is reluctant to carry out my sunnah, then he is not from my group. Get married! Because actually I am proud of the large number of you in front of

11Muhammad Nasib Ar-Rifai, "Taisiru ..., h. 679.

${ }^{12}$ Kementerian Agama RI, Al-Qur,an ..., h. 354.

${ }^{13}$ Muhammad Nasib Ar-Rifai, "Taisiru ..., h. 509.

${ }^{14}$ Ahmad bin Husain Al-Baihaqi, Sunan Al-Baihaqi No. 1782, From CD Maktabah al Ma'arif.

${ }^{15}$ Muhammad bin Yazid bin Majah Al-Quzwaini, Sunan Ibnu Majah No. 2383, From CD Maktabah al Ma'arif. 
the entire ummah. Whoever has the ability (to marry), then marry. And whoever is not able to, let him fast because fasting is a shield for him (from various lusts) ". (H.R. Ibnu Majah)

3. The wisdom of a marriage The lessons of marriage include: 16

a. Biological Needs. The sex instinct is the strongest and most violent instinct that demands a way out. And mating is the natural and biological way that is the best and most suitable for channeling and satisfying this sexual instinct.

b. Form a noble family. Marriage is the best way to make children noble, to reproduce offspring, to preserve human life and to maintain a scripture that Islam is very concerned about.

c. The instinct of compassion. The growth of fatherly and motherly instincts that complement each other, grow feelings of love, kindness, and affection in an atmosphere of life with children.

d. Foster responsibility. There is a sense of responsibility that can lead to diligent, sincere and devoted work.

e. Division of tasks. There is a division of duties for the wife to take care of and manage the household, guide and educate the children, while the husband works outside the home.

f. Strengthening friendship. Can produce kinship ties, strengthen the lasting of love between families and strengthen social relationships.

g. Lowered gaze. Islam encourages marriage. Getting married is more to lower one's gaze, to protect one's genitals, to calm the soul and to protect religion.

4. Rights and Obligations of Husband and Wife

a. Joint Rights of Husband and Wife

With the existence of a marriage contract, husband and wife have joint rights and responsibilities, namely as follows: ${ }^{17}$

1) Husband and wife are allowed to have sexual relations with each other. This action is a necessity husband and wife which is lawful reciprocally. For a lawful husband to do anything to his wife, it is

\footnotetext{
${ }^{16}$ Ahmad Rafi Baihaqi, Membangun Syurga Rumah Tangga, (Surabaya: Gita Mediah Press, 2006), h. 10-12.

17 Drs. Slamet Abidin dan Drs. H. Aminuddin, Fiqh Munakahat 1, (Bandung: CV Pustaka Setia, 1999), h. 157-158.
} 
the same for a wife to her husband. Enjoying relationship enjoyment is a right for husband and wife which is done simultaneously.

2) Marriage is haram, meaning that both husband and wife are not allowed to marry their respective brothers and sisters.

3) With the existence of a marriage bond, both parties will inherit each other if one of the two has passed away even though they have not had intercourse.

4) Children have a clear lineage for their husbands.

5) Both parties are obliged to behave properly, so as to give birth to intimacy and peace in life.

b. Husband's Rights to His Wife

A wife who is pious is a wife who carries out all the rights of her husband, which makes the rights of the husband more important after the rights of Allah and his Messenger. As for the rights of a husband towards his wife that must be implemented are the cases below: 18

1) The wife prioritizes her husband's rights over her family's rights, because the husband's rights are the greatest rights after the rights of Allah and his Messenger.

2) The wife is always ready to be fucked by her husband by always looking beautiful and charming so that the husband always has an appetite for her. Not the other way around, lazy to beautify yourself because it is a refusal to refuse the husband's invitation. Especially if a wife openly refuses her husband's invitation to have intercourse, then that is a big sin. This one right is the most important of the rights of a husband towards his wife. Where there are many disputes and fights caused by this, it is therefore important for a wife to pay attention to this one thing. Unless you refuse the husband's invitation when he is menstruating / childbirth or sick, it is not a problem.

3) The wife does not fast unless with the permission of her husband, whether fasting is obligatory or sunna. Because by fasting the wife will prevent a husband from having fun with his wife during the day, even though it is the husband's right. Unless the wife's fast is 
compulsory fasting and there is no time to do it except for those days, for example a wife has a debt of 7 days of Ramadan fasting, even though the month of Ramadan has 7 days left, it is not permissible for the husband to prohibit it.

4) The wife does not give anything from her house that belongs to her husband except with her permission, even if it is for her family, if this is done then the wife will be guilty while the charity is for her husband.

5) The wife obeys her orders as long as it is not immoral. So it is not obligatory for a wife to obey her husband if the command is a sin.

6) Having a good relationship with her husband, it is forbidden for a wife to shout in front of her husband or to be surly at him.

7) The wife does not leave her house without her husband's permission, even if she is with her neighbors or with her mahram, so also cannot work outside unless her husband allows her.

8) The wife must be qonaah (accepting nature) with what her husband gives, whether a little or a lot, must accept it happily, and not demand it with something that her husband can't get, because it will result in a husband doing things that Allah Subhanahu Wata doesn't approve. 'ala.

9) The wife does not open her genitals except for her husband and mahram, including wearing tight clothes, because it will indirectly reveal her body shape and genitals.

10) The wife is not proud of her beauty towards her husband and does not ridicule her husband's ugliness if that is the case, nor is she proud of her wealth if she is richer than her husband, but instead she always flatteres him and takes care of his feelings.

11) Loves her husband's children both from her and from her other wives, by taking care of her to educate her and not to curse them with bad words, especially by cursing her, because a mother's words are a prayer for her children, good or bad. 
c. Wife's Rights to Her Husband

Just as the husband's rights must be exercised by the wife and vice versa, a wife has rights to her husband which must be exercised by a husband. The rights are as follows: ${ }^{19}$

1) Getting along well, a husband should hang out with her gently, because a woman has feelings and a gentle soul. let alone beating, with harsh words spoken by a husband can offend a wife.

2) A husband should be patient with the behavior of his wife who is not good because indeed the women were created in a state of lack of insight and reason so that they always fall into errors. Especially if the husband is patient from the bad temper of the wife, it is a form of worship that is very rewarding. So as a husband, he must tolerate his wife's weakness, because a wife has given her husband a lot of goodness, from children, enjoyment, to the service of his wife.

3) The husband should invite his wife to joke and flirt because it pleases him.

4) Providing a living to his wife according to his ability in terms of clothing, food and shelter.

5) The husband must teach his wife about his religion if he is able to teach it, and send her to a special women's assembly, because a wife is the responsibility of her husband.

6) The husband must be jealous of his wife to a reasonable extent, by not allowing her to talk to people who are not mahram, not receiving guests if her husband is not at home and so on. But not to the point of spying and finding fault.

7) If the husband is married to more than one person, then it is among the rights of the wife to be fair among them in terms of providing a living, taking turns, and giving an asset.

8) Do not do azal (namely removing sperm from the wife's genitals) unless with the wife's permission.

9) Must protect it from haram acts. It is true that jima 'right belongs to the husband in the sense that if the husband wants it then the wife refuses then the wife sins and vice versa, but if the wife is not intercourse it will cause her to commit adultery, it is obligatory for

${ }^{19}$ K.H. Segaf Hasan Baharun, S.H.I, Bagaimanakah Anda Menikah dan Mengatasi Permasalahannya?, Cet.1, (Pasuruan: Yayasan Ponpes Darullughah Wadda'wah), h. 144-152. 
the husband to have sex with her, in order to protect her from sinning.

10) The husband does not do anything wrong or condemn her either with words or with work, both in terms of his character and body, both for himself and his family. But should glorify him and appreciate him if he loves him and not wronged him if he does not like it.

5. Husband and Wife Relations in the Book 'Uqūd al-Lujain fi Bayān Huqūq al-Zaujain

In the book 'Uqūd al-Lujain fi Bayān Huqūq al-Zaujain is a book related to the discussion of husband and wife, this book consists of four parts, two of which explain the rights and obligations of husband and wife.

In the first part, it explains the rights of the wife that must be fulfilled by the husband, namely being good when hanging out, providing for the wife and dowry, sharing time, teaching the wife what she needs from fardhu and sunnah worship even though it is not recommended (muakkad), everything related to menstruation, and obligations. obey except in immoral things.

In the second part, it explains the rights of the husband that must be carried out by the wife, namely obeying the husband as long as he does not commit immorality, being good in socializing, surrendering himself to the husband, always being at home, keeping himself from cheating, closing himself from the view of others on the body even though face and palms because they see these two parts are punished as haram even without lust and slander, do not demand anything beyond the needs of the husband even though the husband is capable, do not eat the results of the husband's work from haram property, and do not lie about his menstruation whether it is the time of discharge or termination.

In the two sections above, most of the rights and obligations of husband and wife are explained in that section, the explanation above is an explanation of two parts in the book 'Uqūd al-Lujain fi Bayān Huqūq al-Zaujain in brief, following the distribution of rights and obligations of husband and wife in the book' Uqūd al- Lujain fi Bayān 
Huqūq al-Zaujain : ${ }^{20}$

1. The rights of a husband that must be fulfilled by a wife are as follows:

a. A wife may not use her property except with the husband's permission, because she is like a woman who is prevented from using her property.

b. The wife realizes that she is like a slave to her husband.

c. It is obligatory for a wife to keep shame on the side of her husband and lower her gaze in front of him.

d. Obey the husband's orders.

e. Silence when the husband talks and stands up when the husband comes from traveling and welcomes him.

f. Shows love when close and shows pleasure when looking.

g. Invites himself when going to bed.

h. Wear perfume, keep bad breath, dress clean, always make up when in front of her and not make up herself when her husband is not around.

i. It is obligatory for the wife not to cheat and to protect the husband's property when he is not around.

j. It is not lawful for a wife to give food from the husband's house to someone else unless the husband's permission is made, except for wet food which is feared not to be eaten.

k. It is obligatory for the wife to honor the husband's family and honor his relatives.

l. Seeing the husband's small gift with a precious view and receiving it gratefully.

m. Seeing the condition of the husband who always has advantages.

n. Does not prevent/refuse the husband touching himself even though he is on the vehicle except during menstruation or childbirth before bathing even though the blood has stopped.

o. Do not fast other than arafah and ashura 'except with the husband's permission.

$20{ }^{20}$ Imam Nawawi al-Bantani, 'Uqūd al-Lujain fi Bayān Huqūq al-Zaujain, Terj. M. Nasif, Keluarga Berkah: Meraih Kebahagiaan Dunia Akhirat, Cet. I, (Kediri: Turast 2011 \& Lirboyo Press, 2014), h. 44-87. 
p. Do not leave the house unless with the husband's permission.

q. Always take care of your husband's approval and stay away from his anger as much as possible.

r. Don't procrastinate when your husband asks for sex.

s. Do not frown when in front of her husband.

t. Do not ask for divorce to the husband without urgent need.

u. Not to be alone with someone your husband hates and not give permission to enter the house to someone your husband doesn't like.

2. The rights of the wife that must be fulfilled by the husband include:

21

a. Be fair, good in terms of sleep, provide for, and generally be kind in speech.

b. Treat his wife well in matters of clothing and food.

c. Not hitting the face and not abusing his wife.

d. Not indifferent to him, except in bed (indifferent means not having sex in bed).

e. Giving a message of kindness to his wife.

f. Provide a living to the wife according to the level of the husband's ability.

g. Be patient with your wife's behavior, be gentle with her, and guide her to the path of kindness.

h. Teaching both fardhu and sunna worship, from prayer, zakat, fasting, and hajj, if the husband is able to teach it, then it is not permissible for the wife to go out and ask the ulama.

\section{Research methodology}

The type of research used in this research is empirical and normative research, where the researcher goes directly to the field and observes the object under study in order to obtain the data needed in the study, then the researcher reviews the results of the data obtained with the book 'Uqūd al-Lujain fi Bayān Huqūq al-Zaujain.

This research was conducted in the village of Tangga Ulin. This study uses two

${ }^{21}$ Imam Nawawi al-Bantani, 'Uqūd ..., h. 22-43. 
data sources, namely primary data sources and secondary data sources. Primary data, namely data obtained from direct observation and research of research subjects in the form of information or results of observations and interviews conducted by researchers to research subjects. As for the primary data sources in this study were young marriage actors, local communities, religious leaders, and village heads in Tangga Ulin Village. They are people who understand the problem to be researched by researchers and are considered representatives to represent the entire community in Tangga Ulin Village. Secondary data, namely data obtained or collected and compiled by previous studies or published by various other agencies. Secondary data is divided into two, namely a) Primary Material which consists of the book 'Uqūd al-Lujain fi Bayān Huqūq al-Zaujain, and b) Secondary Material which consists of journals, scientific articles, and other scientific works.

Therefore, this research is in the field. Field research is the source of data obtained from the research field, which is looking for data to enter the field into the object of research to obtain concrete data relating to the problem of the relationship husband and wife of early marriage actors. Then review from the perspective of the book 'Uqūd al-Lujain fi Bayān Huqūq al-Zaujain.

To obtain the necessary data, several techniques were used, namely observation, namely making direct observations in the field to find out directly the object of research. Then the interview, namely asking informants to explore and obtain the data needed in the study. As for the stages of data processing and analysis, the authors present the data, followed by data reduction, then data verification and drawing conclusions.

\section{Discussion}

1. Patterns of Husband and Wife Relationships to Early Marriage Actors in Tangga Ulin Village

Domestic life of perpetrators of early marriage at the beginning of marriage experiences various kinds of marital tests, one of which is minor disputes which are very natural at the beginning of marriage because this period is an adjustment to the spouse. Disputes can occur because it is necessary to unite two people into one, which is an adjustment between one another as long as it is still within reasonable limits. The early period of marriage can be called a happy period because initially, you now have a partner who accompanies you, feels happiness at the beginning of marriage, 
even many couples who do early marriages do not experience problems in their household at the beginning of marriage, either disputes or differences of opinion. Households who carry out early marriages that have no problem, namely married couples who have an age gap husband and wife of about 5 years or more, so that the maturity of the husband can be the basis for forming harmony, protecting the wife, and guiding the wife in the household, according to QS. An-Nisa (4) ayat 34 :

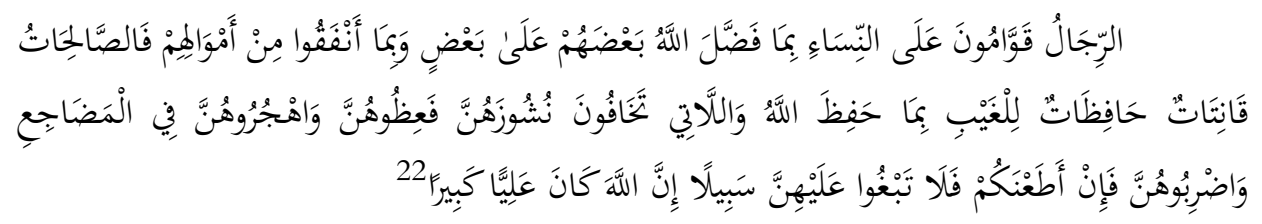

Translation: "Men are leaders for women, because Allah has given them the ability (men) over some of the others (women), and because they (men) have spent part of their wealth. Therefore, a godly woman who is obedient to God takes care of herself when her husband is not there, because God has taken care of (them). The women whom you fear are disobedient, then rebuke them and separate them in their beds, and beat them. Then if they obey you, then don't look for ways to trouble them. Verily Allah is Most High, Most Great. " (QS. An-Nisa (4) : 34)

Included in the meaning of qowwamuna is to lead, straighten if she (woman) is crooked (wrong), nurture, protect, foster and educate. ${ }^{23}$

The relationship between the wife and her husband until now from the beginning of the marriage, through the results of interviews conducted by researchers, shows that the relationship with the husband is fine, there has never been a big problem, causing violence to occur or divorce in the household, divorce in the household is highly avoided because of divorce is something that is hated by Allah SWT, in accordance with the words of Rasulullah.saw :

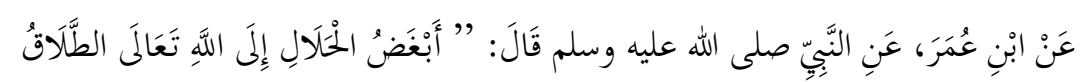

Meaning: From Ibn 'Umar RA, from the Prophet Sallallaahu' alaihi wasallam, he said, "The lawful thing that Allah Ta'ala hates is thalaq (divorce)." (History of Ibn Dawud and Ibn Majah)24

The main factor in the existence of problems in the household is an unstable economic factor that can lead to quarrels, disagreements with

\footnotetext{
${ }^{22}$ Kementerian Agama RI, Al-Qur,an ..., h. 84.

${ }^{23}$ Ahmad Kusyairi Suhail, Menghadirkan Surga di Rumah, (Jakarta: Maghfirah Pustaka, 2007), h. 199.

${ }^{24}$ Sulaiman Rasyid, Fiqh Islam, (Bandung: Sinar Baru Algensindo, 2012), h. 401-402.
} 
parents-in-law if one house with parents, factors from neighbors or family who interfere in household affairs, resulting in quarrels. Actually, in marriage there is no need to listen to neighbors' conversations which will sometimes cause disputes in the household, because the essence of marriage is a physical and spiritual bond between a man and a woman as husband and wife with the aim of forming a happy and eternal family (household) based on a divine Almighty. ${ }^{25}$ From the meaning of marriage, it is clear that in order to form a happy and eternal family (household), there must be a bond husband and wife, without listening to other people's conversations that can destroy the household. It is enough to build a family where both learn and understand each other.

a. In the household there must be disputes, even though only minor problems, but this does not lead to divorce, if there is a difference of opinion that causes disputes in the household then there must be a solution to reconcile it, among several solutions are:

b. Compromised between one another, do not take individual action, and do not let parents, relatives or family find out.

c. Parents mediate if they live in the same house

d. Husband or wife go to parents house to cool off for a while

Every household has its own way of resolving disputes experienced, therefore there are various ways to make peace depending on what the husband and wife want to restore the situation to normal.

From the interviews of researchers with informants, especially with early marriage actors, they really understand the essence of being a wife is to always help and accompany the husband in every situation, they even work to help their husbands to meet the needs of the household economy even though some only sell online or sell together with husband. The wives said there was no problem working together or only the husband making a living, because a harmonious household is preferred without economic problems, so understanding each other between partners is the solution. The husband and wife relationship in the household does not have to apply a bound pattern, but mutual understanding and help with a partner (flexible) can be used as a reference for family to be harmonious. Even

${ }^{25}$ Pasal 1 Bab 1 Dasar Perkawinan Undang-Undang Nomor 1 Tahun 1974. 
though the research informants in this study were early marriage couples, they can live a household in harmony until now, even their marriage ages ranging from 7-22 years of age have been married. Early marriage partners have different motivations and reasons, including: to avoid / stay away from adultery, the desire / coercion of parents, love each other then immediately want to get married, and matchmaking from the family.

\section{Relationship Pattern of Husband and Wife of Early Marriage in Tangga Ulin Village with the Perspective of the Book 'Uqūd al-Lujain fi Bayān Huqūq al-Zaujain}

One of the husband and wife relationships contained in the book 'Uqūd al-Lujain fi Bayān Huqūq al-Zaujain is about the wife's obligation in the section "the wife is encouraged to realize that she is like a slave to the husband." According to the understanding of researchers, that a wife is likened to a husband's slave or in other words, she must always help and accompany her husband in all circumstances and be faithful to her husband.

In the book Qurrotul 'Uyun, Imam Shafi'i gives an opinion about the rights of a husband who is obliged to his wife, namely: "For marriage is like slavery, it is obligatory for a wife to obey her husband absolutely in everything that her husband orders her apart from orders that are contrary to religious law ".26 From the opinion of Imam Shafi'i, he gave the same view as the statement stated in the book 'Uqūd al-Lujain fi Bayān Huqūq al-Zaujain regarding the position of the wife as a slave to the husband. It does not mean the word slave means a wife like a servant, but obedient and obedient to her husband, that is like a slave, who always carries out the husband's orders and serves her husband wholeheartedly while not contradicting religious law. Even in a hadith Rasulullah saw said:

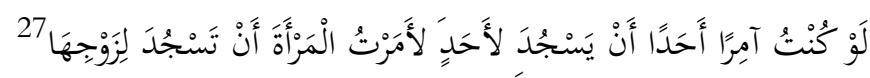

Meaning: "If I am ordered to prostrate to another person, then surely I will order a woman (wife) to prostrate to her husband.".

\footnotetext{
${ }^{26}$ Asy Syeikh Imam Abu Muhammad, Terjamah Qurrotul 'Uyun, Terj. Ahmad Najieh, (Surabaya: Mutiara Ilmu, 2013), h. 74.

${ }^{27}$ Hadits hasan shahih: Narrated by at-Tirmidzi (no. 1159), Ibnu Hibban (no. 1291 al-Mawaarid) dan al-Baihaqi (VII/291), From Abu Hurairah radhiyallaahu 'anhu.
} 
The hadith explains that the high position of the husband over the wife, even if it is permissible for someone to prostrate against another, then the wife will be ordered to prostrate against the husband. When a woman is married, all her responsibilities that were initially borne by her father are transferred to her husband, and it can be said that heaven and hell, the wife depends on the husband, because a wife is very easy if you want to enter heaven just by doing 4 things then you can enter heaven from which door course, according to the hadith of the Prophet Saw that is :

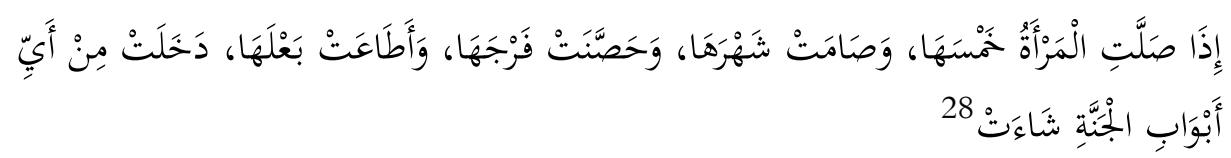

Meaning: "If a wife prays the five daily prayers, fasts in the month of Ramadan, takes care of her genitals (maintains her honor), and is obedient to her husband, undoubtedly she will enter Heaven from whatever door she wants.".

In Tangga Ulin Village, there are several religious leaders who often hold and fill recitations. The results of interviews with informants (several religious leaders) show that they often provide explanations about households in their recitation. One of the books that is used as a reference is the book 'Uqūd al-Lujain fi Bayān Huqūq al-Zaujain, especially in women's special assemblies it is often explained how to be a wife in a household based on the book. The book 'Uqūd al-Lujain fi Bayān Huqūq alZaujain contains the rights and obligations of husband and wife, as well as about the virtue of a woman to live at home.

Based on interviews with informants from religious leaders in Tangga Ulin Village, the community often listens to lectures in recitation of the relationship husband and wife according to the book 'Uqūd alLujain fi Bayān Huqūq al-Zaujain, especially in women's assemblies. as for its application in the household, depending on each person. Many people understand the rights and obligations of husband and wife, but in practice it is sometimes not appropriate. This is because in the household they apply a husband and wife relationship that is not binding (flexible), helps each other and understands between partners, so that in carrying out 
household duties it is not only done by the wife or vice versa, and is not fixated on the relationship husband and wife who are bound and focused on each other's responsibilities without helping the partner.

\section{E. Conclusion}

The husband and wife relationship of the perpetrators of early marriage in Tangga Ulin Village applies a husband and wife relationship pattern that is not bound (flexible), in carrying out their respective rights and obligations to help and understand each other between partners, so that they can ease the work and responsibilities that exist in their household. Even with the background of early marriage, the household can live in harmony for 7-22 years.

According to the book 'Uqūd al-Lujain fi Bayān Huqūq al-Zaujain especially the section "wives are encouraged to realize that they are like slaves to their husbands." However, in its application, it applies a pattern of mutual help and understanding (flexible) relationships. Although the contents of the book are often explained or quoted by speakers in Tangga Ulin Village during the recitation of women. 


\section{Bibliography}

\section{Book}

Abidin, Slamet dan Aminuddin.Fiqh Munakahat 1. Bandung: CV Pustaka Setia, 1999.

Al-Baihaqi, Ahmad bin Husain. Sunan Al-Baihaqi No. 1782. From CD Maktabah al Ma'arif.

Al-Bantani, Imam Nawawi. 'Uqūd al-Lujain fi Bayān Huqūq al-Zaujain. Terj. M. Nasif.Keluarga Berkah: Meraih Kebahagiaan Dunia Akhirat.Cet. I. Kediri: Turast 2011 \& Lirboyo Press, 2014.

Al-Jaziri, Abdurrohman. Al-Fiqh Ala Al-Madzahib Al-Arba'ah. Cet. I. Lebanon: Darul Kutub Al-Ilmiah Beirut, 2013.

Al-Quzwaini, Muhammad bin Yazid bin Majah. Sunan Ibnu Majah No. 2383. From CD Maktabah al Ma'arif.

Anggota ABRI dkk.Undang-Undang Pokok Perkawinan. Jakarta: Bumi Aksara, 1999.

Ar-Rifai, Muhmmad Nasib. "Taisiru al-Aliyyul Qadir li Ikhtishari Tafsir Ibnu Katsir" Terj., Syihabuddin.Kemudahan dari Allah: Ringkasan Tafsr Ibnu Katsir. Cet. I. Jakarta: Gema Insani, 1999.

As'ad, Abdullah Muhaimin. Risalah Perkawinan. Surabaya: Bintang Terang, 1987.

Asy-Syafi'i, Imam Taqiyuddin Abu Bakar bin Muhammad Al-Husaini AdDimasqi."Kifayatul Akhyar fi Halli Ghadayatil Ikhtishar" Terj., Rohmatullah Ngimanuddin.Kifayatul Akhyar: Memahami Fikih Mazhab Syafi'i. Cet. I. Solo: Al-Qowam, 2016.

Badan Pusat Statistik HSU.Kabupaten Hulu Sungai Utara Dalam Angka 2016. Hulu Sungai Utara: BPS-Hulu Sungai Utara, 2016.

Baharun, Segaf Hasan.Bagaimanakah Anda Menikah dan Mengatasi Permasalahannya? Pasuruan: Yayasan Ponpes Dalwa, 2005.

Baihaqi, Ahmad Rafi.Membangun Syurga Rumah Tangga. Surabaya: Gita Mediah Press, 2006.

Departemen Pendidikan Nasional.Kamus Bahasa Indonesia. Jakarta: Pusat Bahasa, 2008

Emzir.Metodologi Penelitian Kualitatif Analisis Data. Jakarta: PT Raja Grafindo Persada, 2010.

Ghazaly, Abd. Rahman.Fiqh Munakahat. Surabaya: Prenada Media, 2019.

Herdiansyah, Haris. Metode Penelitian Kualitatif untuk ilmu-ilmu sosial. Jakarta: Sinar Grafika, 2012.

Ismail, Didi Jubaedi dan Maman Abdul Djaliel.Membina Rumah Tangga Islam di Bawah 
Rida Illahi. Bandung: Pustaka Setia, 2000.

Jubaedi, Dedi.Bimbingan Perkawinan: Membina Keluarga Sakinah menurut Al-Qur'an dan As-Sunnah. Jakarta: Akademik Pressindo, 2000.

Kementerian Agama RI. Al-Qur,an Madina. Bandung: PT Madina Raihan Makmur, 2013.

Luthfiyati, Dian.Metodologi Penelitian Kesehatan. Jakarta: Rineka Cipta, 2008.

Milles dan Hubberman.Analisis Data Kualitatif. Jakarta: UIP, 1992.

Muhammad, Syaikh Kamil ‘Uwaidah.Fiqih Wanita, Jakarta: Pustaka Al-Kautsar, 1998.

Muthahhari, Murtdha. Wanita dan Hak-Haknya dalam Islam. Terj. M. Hashem. Bandung : Pustaka, 1985.

Nasir, Jamal J. "The Islamic Law of Personal Status." Third Edition. The Hague/London/New York: Kluwer Law Internasonal, 2002.

Rasyid, Sulaiman.Fiqih Islam. Jakarta: Ath Thahiriyah, 1976.

Soemiyati.Hukum Perkawinan Islam dan Undang-undang Perkawinan. Yogyakarta : Liberty Yogyakarta, 1989.

Sudjijono, Anas. Pengantar Statistic Pendidikan. Jakarta: Raja Grafindo, 2006.

Sugiyono.Metode penelitian Kuantitatif, Kualitatif dan R\&D. Bandung: CV. Alfabeta, 2009.

Metode Penelitian Kualitatif. Cet 1. Bandung: Alfabeta, 2017.

Syarifuddin, Amir. Hukum Perkawinan Islam di Indonesia: Antara Fiqh Munakahat dan Undang-Undang Perkawinan. Jakarta: Kencana, 2007.

Thalib, Sayuti.Hukum Keluarga Indonesia. Jakarta: UI-Press, 1986.

Yunus, Mahmud.Hukum Perkawinan dalam Islam. Jakarta: Hidakarya Agung, 1977.

\section{Journal}

Rifiani, Dwi.“Pernikahan Dini dalam Perspektif Hukum Islam”, dalam Jurnal Syariah dan Hukum edisi no. 2, Vol. III, 2011.

Zuhrah, Fatimah. "Relasi Suami dan Istri dalam Keluarga Muslim Menurut Konsep AlQur'an: Analisis Tafsir Maudhuiy", dalam Jurnal Analytica Islamica edisi no. 1, Vol . II, 2013.

\section{Regulations}

Kompilasi Hukum Islam, "Dasar-Dasar Perkawinan” Bab II Pasal II.

RepublikIndonesia . Undang-Undang Republik Indonesia Nomor 16 Tahun 2019 Tentang Perubahan Atas Undang-Undang Nomor 1 Tahun 1974 Tentang Perkawinan, Pasal 7. 
Undang-Undang, “Dasar Perkawinan” Nomor 1 Tahun 1974, Bab I pasal I. 